\title{
State Regulation of Financial Position of Territories
}

\author{
Natalia A. Istomina*, Yulia S. Dolganova, Veronica S. Koskova \\ Chair of finance, monetary circulation and credit, Ural State University of Economics, Yekaterinburg, Russia \\ *Corresponding author.E-mail: n_istomina_usue@mail.ru
}

\begin{abstract}
The article presents the results of the study on the inseparability of administrative regulation of debt of constituent entities of the Russian Federation and provision of federal inter-budget transfers to highly dependent territories. The authors study modern trends related to providing territories with inter-budget transfers both in foreign and domestic scientific literature. Besides, the level of financial dependence of highly subsidized territories of the Russian Federation is detected and evaluation of significant changes in the indicators of own revenues and debt of highly subsidized entities of the Russian Federation in connection with measures of state financial regulation is provided. The need for legislative financial regulation in the format of establishing mandatory parameters for the constituent entities of the Russian Federation through the example of the debt situation in high-level regions is proved.
\end{abstract}

Keywords: constituent entity of the Russian Federation, direct financial regulation, inter-budget transfers, debt

\section{INTRODUCTION}

Differentiation of constituent entities of the Russian Federation according to most social, economic and other parameters is an objective characteristic / problem of our state and an occasion for administrative action. The importance of this problem lies in the fact that different regions of Russia have different initial prerequisites for development, which entails unequal attractiveness for the population, investors, different potential in terms of budget revenues, etc.

This problem is directly related to the practical tasks of the current stage of state development. Recently, the country's leadership and executive authorities have been consistently solving practical tasks aimed at creating equal opportunities for the Russian population in terms of access to social services (primarily education and healthcare), and the level of infrastructure development. This should create the basis for achieving national goals reflected in national projects. In the end, we can talk about the approximation of indicators of various constituent entities of the Russian Federation to certain standards, i.e. reducing the level of regional differentiation.

From the standpoint of importance of the problem under consideration, it should be noted that the issues of territorial development have always been in the purview of scientific researchers. An essential scientific task of the current stage is validation of resources for sustainable development of regions and municipalities against the backdrop of external threats and internal problems of territories. A sustainable development of regions, characterized by differentiation of the constituent entities of the Russian Federation according to most social, economic and other parameters, is possible only if the objective territorial characteristics and integrated efforts of various levels of government aimed at smoothing out territorial differences are taken into account.

As part of the efforts of federal authorities, financial regulation is an important component. This activity is primarily based on intergovernmental transfers to the constituent entities of the Russian Federation (direct financial regulation). In addition, the state carries out legislative regulation in the format of establishing mandatory parameters for the constituent entities of the Russian Federation.

\section{BACKGROUND}

For any federal state, the problem of distribution of financial resources between territories is always relevant, and studies of the 21 st century show that even in unitary states the concepts of 'centralization/decentralization' are used. A review of foreign studies shows that mainly developing countries (Argentina, Indonesia, Kenya, China, Mali, Morocco, Uruguay, the Philippines and others) are concerned with the problem of equalizing the financial situation of the territories (at the subfederal and local levels). A similar situation is being observed in Russia - the bulk of the research is devoted to the 'problematic' - highly subsidized regions: the North, the Caucasus, the Far East, and border territories. There are several directions to financially equalize the territories. However, the preferred direction is debatable. 
It must be remembered that in itself, 'optimization of the debt' volume and structure is not yet an indicator of the qualitative and effective management of the subfederal debt' [17, p. 72], and only considering the growth of real financial independence, we can evaluate the effectiveness of debt management. Thus, the values of transfers and debt are interconnected.

\section{RESEARCH PURPOSE AND OBJECTIVES}

The aim of the study is to confirm the hypothesis that within the framework of state measures to regulate the financial situation of regions it is not possible to significantly adjust the level of financial selfsufficiency of the constituent entities of the Russian Federation (which remains relatively constant), but a substantial change in absolute debt indicators is possible due to administrative measures.

The research objectives are:

1. Evaluation of the share of inter-budget transfers in the revenue structure of highly subsidized constituent entities of the Russian Federation and assessment of dynamics of this indicator for the period of 2015-2018.

2. Evaluation of the ratio of the debt of constituent entities of the Russian Federation and the revenues of highly subsidized constituent entities of the Russian Federation and assessment of dynamics of this indicator for the period of 2015-2018.

3. Assessment of significant changes in terms of indicators of own revenues and debt of highly subsidized constituent entities of the Russian Federation in connection with measures of the state financial regulation.

The following are considered as assumptions: for constituent entities of the Russian Federation, the indicators of the consolidated budget revenues are accepted as budget revenue parameters; the sum of the debt of a constituent entity of the Russian Federation and the debt of municipalities located within the territory of this constituent entity of the Russian Federation are considered as an absolute amount of debt. The Federal Statistics Service and the Ministry of Finance of the Russian Federation serve as sources of information.

\section{RESULTS}

Based on the study [16], highly subsidized constituent entities of the Russian Federation include: the Republic of Tyva, the Chechen Republic, the Republic of Dagestan, the Republic of Ingushetia, the Republic of Crimea, the Republic of Altai, the Kamchatka Krai, the City of Sevastopol, and the Karachay-Cherkess Republic. According to the Ministry of Finance of the 
Based on the presented data, we can formulate the obtained scientific results:

- the level of financial dependence of highly subsidized constituent entities of the Russian Federation, basically, remains at a certain level typical for each constituent entity (this is most clearly manifested by the example of the Republic of Tyva, the Republic of Dagestan, the Republic of Altai and the Kamchatka Krai);

- the growth of the absolute amount of budget revenues of highly subsidized regions is to a certain extent connected with the growth in the volume of interbudget transfers from the federal budget (the highest rate of revenue growth from 2015 to 2018 is typical for the Republic of Crimea and the city of Sevastopol);

- due to financial injections from the federal budget, an increase in indicators of regional budgets is achieved, i.e. the degree of financial differentiation of regions decreases; however, the growth of financial independence does not occur (it can be noted through the example of the Karachay-Cherkess Republic, where from 2016 to 2018, the absolute amount of consolidated budget revenues increased by more than 5 billion rubles, while the share of inter-budget transfers increased from 59.30 to $67.28 \%$ );

- most of the highly subsidized constituent entities of the Russian Federation examined during the period of 2015-2018 (the Republic of Crimea: from 2016 to 2018) are characterized by a decrease in both the absolute amount of debt and the percentage of debt and the amount of consolidated budget revenues; this trend is pronounced and stable;

- a specific debt situation is characteristic - to a certain extent - of the Karachay-Cherkess Republic (fluctuations in the absolute value of debt with a stable tendency to debt decrease in relation to the amount of budget revenues) and of Sevastopol (absence of debt);

- the decrease in the absolute amount of debt of the constituent entities of the Russian Federation as a whole (not only in relation to highly subsidized regions) is determined by the government policy that has been implemented in recent years to control the debt situation of the territories;

- for highly subsidized constituent entities of the Russian Federation, the criteria introduced by the Government of the Russian Federation regarding indicators related to the debt situation are the most stringent and dictate a model of minimum financial freedom, which meets the general requirements for the financial situation of problem territories.

\section{CONCLUSIONS}

The state policy of increasing financial resources of highly subsidized territories, the purpose of which is to reduce the level of differentiation of territories, consolidates a low level of financial independence of 
University, 2011, no. 343, pp. 148-151. https://www.elibrary.ru

[4] J. Lopez-Laborda, A Zabalza. Intergovernmental fiscal relations: the efficiency effect of taxes, transfers, and fiscal illusion, Environment and Planning CGovernment And Policy, vol. 33, no.1, pp. 136-162. https://webofknowledge.com

[5] K. Yuya, T. Toshiki. Tax competition, unemployment, and intergovernmental transfers // International tax and public finance, 2019, vol. 26, no. 4, pp. 899-918. https://webofknowledge.com

[6] A.F. Munoz,G.A. Radics, C. Bone. Subnational Fiscal Disparities and Intergovernmental Transfers in LAC, Hacienda publica espanola-review of public economics, 2016, no. 219. https://webofknowledge.com

[7] L.M. Borshch. System of interbudgetary relations. sources of formation of the consolidated budget, Scientific bulletin: finance, banks, investments, 2019, no. 3(48), pp. 5-12. https://www.elibrary.ru

[8] T. Gurbanova. The elements of the mechanism of budgetary regulation and strategy of budget policy management, Economic and social development (ESD 2019): 37th international scientific conference on economic and social development - socio economic problems of sustainable development, 2019, pp. 14401444. https://webofknowledge.com

[9] M.A. Pechenskaya. Research in the functioning of the regional budgetary system, Economic and social changes-facts trends forecast, vol. 41, no. 5, pp. 147 158. https://webofknowledge.com

[10] L. Muinelo-Gallo, A.R. Miranda, P.C. Scavone. Intergovernmental transfers and regional income inequalities: an empirical analysis of Uruguay, Hacienda publica espanola-review of public economics, 2016, no. 219. https://webofknowledge.com

[11] N.M. Klimentieva, V.E. Uliankin. The role of inter-budgetary transfers in formation of the financial potential of the territories, Actual issues of modern science and society, no. 1 (18), pp. 42-45. https://www.elibrary.ru

[2] S.M. Makeikina. Development of mechanisms of interbudgetary regulation, Bulletin of the Volga University of V.N. Tatishchev, 2016, vol. 2, no. 1, pp. 201-206. https://www.elibrary.ru

[3] M.G. Polozkov. Stimulating system of budgetary equalizing of territories, Bulletin of Tomsk State
[12] V.G. Kostenkova. Reforming intergovernmental relations in Russia as a factor in the strategic development of regions, Budget as a subject of social sciences: Collection of articles of a scientific and practical conference. Izhevsk: Publishing House 
[16] M.V. Milchakov. Highly subsidized regions of

«Udmurt University», 2019, pp. 64-69.

https://www.elibrary.ru

[13] O.V. Nikulina, N.A. Ragozina. Investigation of financial policy of dotation regions of Russia,

Sustainable Development Economics, 2018, no.3 (35), pp. 160-165. https://www.elibrary.ru

[14] T.Y. Tkacheva, L.V. Afanasjeva. Developing the forms of budget regulation for smoothing the imbalances of regional growth, SGEM 2016, BK 2:

Political sciences, law, finance, economics and tourism conference proceedings, vol. III, pp. 175-179. https://webofknowledge.com

[15] M. Jean-Francois, S. Muhammad-Kabir. National or political cake? The political economy of intergovernmental transfers in Nigeria, Journal of economic geography, 2019, vol. 19, no. 5, pp. 1119 1142. https://webofknowledge.com
Russia: conditions for budgeting and state support mechanisms, Financial journal, 2017, no. 1, pp. 22-38. https://www.elibrary.ru

[17]M.N. Palyushok. Debt policy of the subject of the Russian Federation in modern conditions, Bulletin of the Kabardino-Balkarian Scientific Center of the Russian Academy of Sciences, 2008, no. 6 (26), pp. 7278. https://www.elibrary.ru

[18] The volume and structure of public debt of the constituent entities of the Russian Federation and the debt of municipalities.

https://www.minfin.ru/ru/perfomance/ public_debt/subdbt

[19] Regions of Russia. Socio-economic indicators. 2018: Statistical compilation / Rosstat. - M., 2018. 1162 p. https://www.gks.ru/storage/mediabank/Regpok18.pdf 